\title{
Realistic Simulation Tool for practical Analysis of Solar Cooling Thermal Systems driven by Linear Fresnel Collectors
}

\author{
Juan J. Diaz * (iD), José A. Fernández iD \\ Departamento de Ingeniería Energética, Escuela Técnica Superior de Ingenieros Industriales, Universidad Politécnica de \\ Madrid, José Gutiérrez Abascal 2, 28006 Madrid, España
}

https://doi.org/10.54139/revinguc.v28i3.48

\begin{abstract}
The objectives of this study were to develop a realistic simulation tool to analyze solar thermal cooling systems driven by Fresnel collectors and carry out a case study in which the performance of a solar cooling system of $190 \mathrm{~kW}$ located in Riyadh is simulated to demonstrate the functionality and potentiality of the developed tool. This tool is based on an integrated mathematical model that considers the ambient conditions, the thermal loads of the building, the pre-sizing data of each of the components of the system and the simultaneous interaction among them, to conduct a realistic, simple, and precise analysis. A demonstrative simulation example was performed. During the month of July, with a solar opening area of $704 \mathrm{~m}^{2}$ and a tank of $35200 \mathrm{~L}$, a total amount of $47,5 \mathrm{MWh}$ of cooling energy was obtained, with a reduced contribution of the auxiliary system $(5,6 \mathrm{MWh})$ and a minimum number of solar collector system deactivation hours $(0,7 \%)$. The daily COP of the absorption machine remained above 0,69 . The obtained results from the case study with the simulation tool allowed to verify its functionality, capabilities and correct operation to carry out hourly and parametric studies of this type of systems.
\end{abstract}

Keywords: solar energy; linear Fresnel collector; absorption cooling; stratified thermal storage tank; hourly and parametric simulation; HVAC systems; simulation tool.

\section{Herramienta de simulación realista para el análisis práctico de sistemas térmicos de refrigeración solar impulsados por colectores lineales Fresnel}

\begin{abstract}
Resumen.- Los objetivos del presente trabajo consistieron en el desarrollo de una herramienta de simulación realista de sistemas térmicos de refrigeración solar impulsados por colectores Fresnel, y la realización de un caso de estudio que simulara el comportamiento de una instalación de refrigeración solar de $190 \mathrm{~kW}$ localizada en Riad; para demostrar la funcionalidad y potencialidad de la herramienta desarrollada. Esta herramienta se basa en un modelo matemático integrado que considera las condiciones ambientales, las cargas térmicas del edificio, los datos de pre-dimensionamiento de cada componente del sistema y la interacción simultánea entre ellos, para realizar un análisis preciso, simple y realista. Del caso de estudio, realizado en el mes de julio con $704 \mathrm{~m}^{2}$ de apertura solar y un tanque de almacenamiento de $35200 \mathrm{~L}$, se obtuvieron 47,5 MWh de energía de refrigeración, con una reducida contribución del sistema auxiliar $(5,6 \mathrm{MWh})$ y una mínima cantidad de horas de desactivación del sistema de captación solar $(0,7 \%)$. El coeficiente de rendimiento (COP) diario de la máquina de absorción se mantuvo sobre 0,69 . Estos resultados obtenidos con la herramienta de simulación, permitieron verificar su funcionalidad, capacidades y correcta operación, en la realización de estudios horarios y paramétricos de este tipo de sistemas.
\end{abstract}

Palabras clave: energía solar; colectores lineales Fresnel; refrigeración por absorción; simulaciones horarias y paramétricas; herramienta de simulación.

Received: October 30, 2021.

Accepted: December 04, 2021.

\section{Introduction}

In recent years, the refrigeration demand has been increasing and it is expected to maintain an exponential trend for the next decades [1]. The influence of air conditioning, commercial and industrial refrigeration systems on the level and quality of life of populations is getting bigger as 
well as for the development of activities in the various sectors of the current economy.

The growth in the refrigeration demand will have an impact on the electrical generation system because the vast majority of conventional refrigeration systems used today are powered by electricity. It is expected that by 2050 a high percentage of electrical consumption will be due to the demand for refrigeration [1], which will result in the increase in the use of fossil fuels, in the generation of greenhouse gases and its corresponding consequences on climate change.

Due to the implications of the growth of cooling demand, it will be necessary to implement more environmentally friendly, reliable and affordable alternatives in order to avoid the effects on climate change. These effects would occur if the current and conventional practices in the field of cooling systems continue to be used. One of the possible alternatives to implement is the solar thermal cooling systems, reason enough to continue working on the improvement of this technology in order to achieve a reduction in its costs and optimize its operation.

In recent years, the market for solar cooling systems has been increasing, partly due to a reduction in costs and another due to the advances and innovations achieved. According to the International Energy Agency [1] it has been estimated that 1350 thermal solar cooling systems had been installed around the world by 2015, $80 \%$ in Europe, mainly in Spain, Italy and Germany.

Moreover, in accordance with [2] until 2007, 81 large-capacity solar cooling systems were installed, 73 installations located in Europe, 7 in Asia (China), and one in America (Mexico). About $60 \%$ of those installations were dedicated to office buildings, $10 \%$ to factories, $15 \%$ to laboratories and education centers, $6 \%$ to hotels and the remaining percentage to buildings with different final uses (hospitals, canteens, sport centers, etc.). From these 81 solar cooling systems installed; in 56 installations, absorption chillers were used, in 10 others, adsorption chillers and in the last 17, desiccant evaporative cooling systems (DEC). Among the DEC installations, only two systems use a liquid regenerator (DEC liquid).
Recent published studies [3] have estimated that until 2019 more than two thousands solar cooling systems have been installed around the world, $70 \%$ of those were low capacity systems and located in Europe. In addition, according to [3] between 2008 and 2018, 19 large-scale solar cooling systems have been installed, from which $26,4 \%$ are driven by evacuated tube collectors, $21 \%$ driven by Fresnel collectors, 42,10 \% with flat plate collectors and $10,5 \%$ driven by parabolic trough collectors.

In the researching field, solar cooling systems have been studied for more than 50 years [4] and in the last decade research in this area has multiplied, achieving technical improvements that have contributed to their implementation. In this period, several configurations have been studied and analyzed in terms of stages, absorberrefrigerant pairs, drive medium, applications and cooling capacities. In the literature, studies of solar cooling thermal systems have been found with single-effect absorption machines and driven by various types of solar collectors: with nonconcentrating or stationary solar collectors [4, 5, 6, 7, 8, 9, 10, 11, 12, 13, 14, 15, 16], with parabolic cylinder collectors [6, 14, 17, 18] and with linear Fresnel collectors [19]. Also, systems with absorption machines with two or more stages and with various types of solar collectors: with parabolic cylinder collectors [4, 20] and with linear Fresnel collectors [21].

Another key research area regarding the generation of cooling from solar energy is the use of concentrating solar power (CSP) for combined heating/cooling and power generation. To date, different CSP generation systems such as: solar tower, parabolic trough, parabolic dish, linear Fresnel collector, etc., have been studied in different configurations and applications for the generation of heating, cooling and power. A fact that can be observed in the various studies carried out so far [22, 23, 24, 25, 26, 27, 28, 29].

As it can be seen from the information shown above, of all solar cooling systems installed in the world to date, the vast majority of those are powered by non-concentrating or stationary solar collectors, mainly flat plate collectors (FPC). This same behavior is observable in the research on solar 
cooling technology carried out until today. Despite being a technology studied for many years, these studies have mainly focused on the analysis of solar cooling thermal installations driven by stationary solar collectors, leaving out some areas of this technology to be studied and analyzed in the future.

One of these areas still to be explored is the solar cooling systems driven by concentrating solar collectors, specifically what refers to the overall dimensioning of the installation and its influence on operation, functioning and control. To deepen the knowledge on the aforementioned subject, it is necessary to have computer tools capable of simulating the performance of this type of systems in a more realistic way.

In a high percentage of the consulted literature, the main used analysis tool has been the TRNSYS software [25]. Most of the solar cooling installations simulated with this software have been carried out using predefined blocks from the program library to define each component of the system (solar collector, absorption chiller, heat exchanger, storage tank, cooling tower, etc.).

Through the predefined blocks, it is possible to study and analyze the performance of the installations but in a quite theoretical way, since in some cases, the blocks are not programmed from the mathematical equations that define their behavior (for example block 107). In other cases, the blocks keep fixed some inputs that in a real scenario they would have values variables. These aspects influence in the design and operation of the installation, and the obtained results are distant from a realistic performance.

Block 107 is commonly used to simulate the absorption chiller, and this is an example of what was previously explained. This block is not programmed from the equations that define its thermodynamic cycle, instead it uses an external performance data file (from manufacturer datasheet) in order to predict the chiller performance for rated design condition. This means that for a selected chiller, no part load performance curve is available. The aforementioned would require that the rest of the installation is designed to maintain the rated design conditions of the chillers to avoid unreliable results due to extrapolation outside of the manufacturer data.

In addition, the use of the predefined blocks does not allow to examine the installation components from a design point of view, that is, if the user requires to modify any of the internal parameters of any of the installation components to know its influence on the installation, it would not be possible to do so. Having this possibility would allow to examine and find optimization points in the design and operation of the system.

Considering all the aforementioned, this work focuses on two main tasks:

- Firstly, to develop a new realistic simulation tool for analyzing solar cooling absorption systems driven by linear Fresnel collector.

- Secondly, to simulate a case study to demonstrate the applicability, functionality and capabilities of the developed simulation tool. The case study consists in a solar cooling installation with $190 \mathrm{~kW}$ of peak cooling capacity, composed of a Libr- $\mathrm{H}_{2} \mathrm{O}$ single-effect absorption chiller driven by linear Fresnel collector. The proposed solar cooling system generates chilled water for conditioning a main substation facility that operates for the maintenance of the railway installations located in Riyadh.

The developed simulation tool is characterized by:

a) being specifically conceived for analyzing solar cooling thermal systems driven by linear Fresnel collector.

b) having the possibility of defining the features of its components from real pre-sizing data.

c) having the capacity for carrying out sequential and simultaneous simulations to study installations in a global way or focused on the individual performance of its components, even in off rated design conditions.

These characteristics constitute the main novelties of the present work. Another innovative aspect is the inclusion and coupling of a module for the 
Table 1: Boundary conditions of the proposed system

\begin{tabular}{|c|c|}
\hline Parameters & Value \\
\hline $\begin{array}{l}\text { Maximum temperature in sub- } \\
\text { circuit } A\left(T \_A \_m a x\right)\end{array}$ & $180^{\circ} \mathrm{C}$ \\
\hline $\begin{array}{l}\text { Stored water maximum average } \\
\text { temperature }\left(\mathrm{T} \_ \text {tank_max }\right)\end{array}$ & $160^{\circ} \mathrm{C}$ \\
\hline 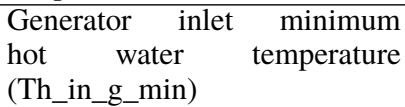 & $80{ }^{\circ} \mathrm{C}$ \\
\hline $\begin{array}{lr}\text { Generator inlet } & \text { maximum } \\
\text { hot water } & \text { temperature } \\
\text { (Th_in_g_max) } & \end{array}$ & $110^{\circ} \mathrm{C}$ \\
\hline
\end{tabular}

The mathematical model of the present work has been developed using the Engineering Equation Solver program (EES) (http://fchartsoftware.com/ees/). It consists of a main program that integrates and interconnects: (1) subroutines containing the governing equations for the system components of a solar cooling thermal installation (submodules), (2) input data and (3) a set of control statements. The resolution of the mathematical model is carried out through a parametric table that interacts with the main program window by means of specific programming statements as well as with variables that serve as bridge among them. These bridge variables allow to exchange information among the parametric table, the control procedure, and the base/main mathematical model in the main window.

The structure diagram of the developed mathematical model in this work is presented in Figure 3.

\subsubsection{Input Data}

- Thermodynamic properties of working fluids.

The boundary conditions of the proposed system used for simulations are presented in Table 1 .

\subsection{Mathematical model}

An integrated mathematical model based on an hourly simulation engine has been developed to study and analyze thermal installations of solar cooling in a dynamic, transient and parametric way. This analysis would be performed considering the pre-sizing data of the installation components based on information provided by manufacturers and entered by the user.
The thermodynamic properties of $\mathrm{H}_{2} \mathrm{O}$, dry air, air- $\mathrm{H}_{2} \mathrm{O}$ and $\mathrm{LiBr}-\mathrm{H}_{2} \mathrm{O}$ used to carry out the simulations are provided by an internal thermophysical property database of EES and introduced into the base/main model through internal functions provided by EES. On the other hand, the thermodynamic properties of the different heat transfer fluids used in the absorbers of solar collectors have been provided by the manufacturer (https://www.therminol.com/heat-transferfluids). This information is introduced in the 


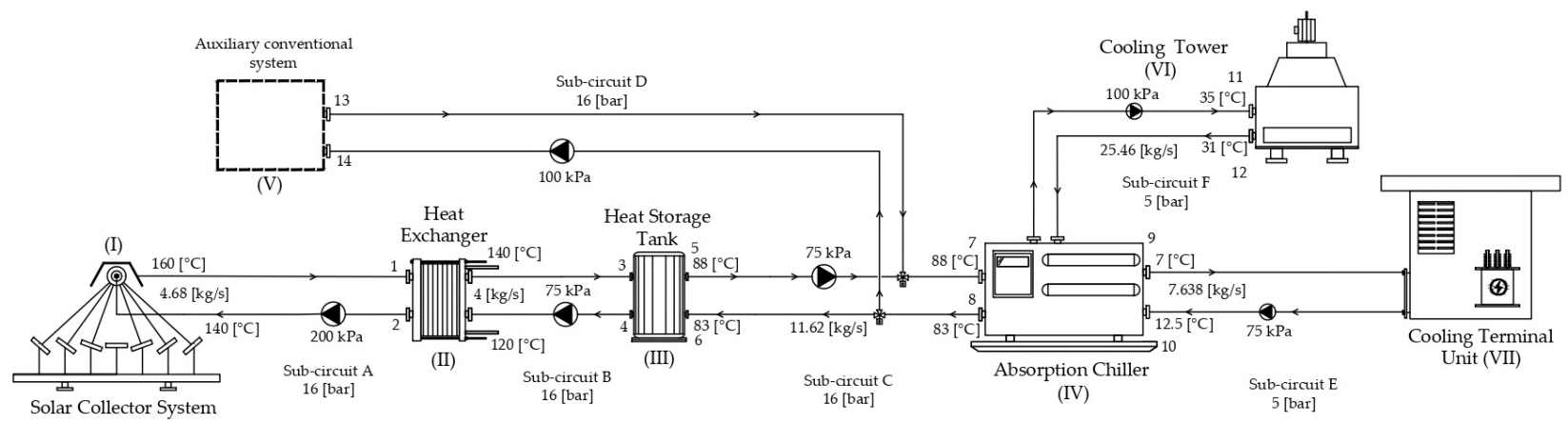

Figure 1: Schematic Diagram of the proposed thermal solar cooling System

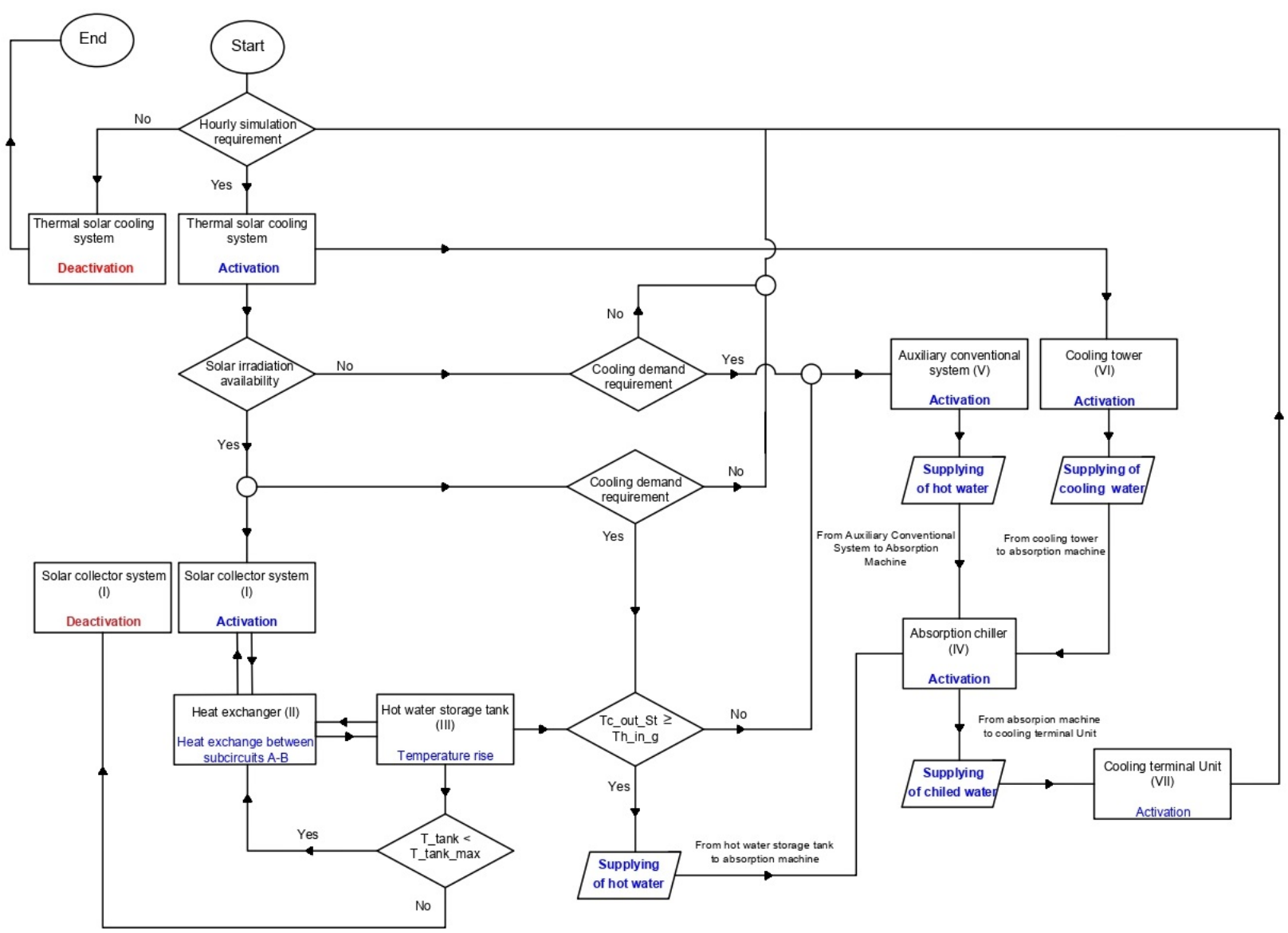

Figure 2: General operating conditions of the proposed thermal solar cooling system

base/main mathematical model through the insertion of lookup tables (the lookup table is a tool offered by EES for the introduction and management of data that can be used to solve equations).

- Pre-sizing data of each component of the system.
The information provided by the manufacturers is used to characterize the various equipment and components of the solar cooling thermal system, considering the requirements of the installation to be simulated. In those cases, in which the manufacturers cannot explicitly provide the necessary information, the mathematical module of the component 


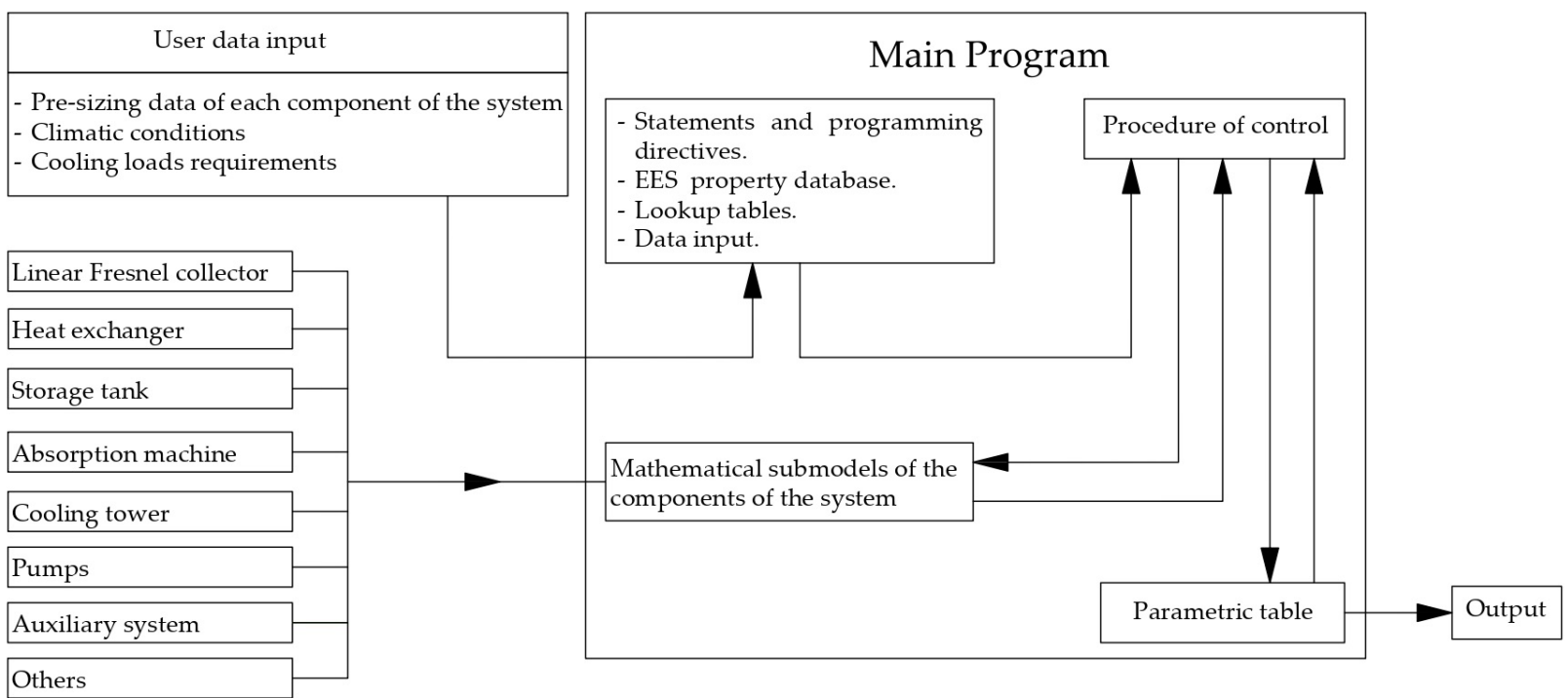

Figure 3: Structure diagram of the developed simulation tool in EES

is then used in conjunction with information of datasheets to estimate the required data, through an iterative process.

- Weather data.

The climatic information to carry out hourly simulations are entered in the base/main mathematical model through the insertion of lookup tables. Depending on the country where the study is carried out, different sources can be used to obtain climate information (https://energyplus.net/weather).

- Cooling Load requirements.

The hourly profile of cooling load requirements throughout a typical year $(8760 \mathrm{~h})$ is obtained from a detailed preliminary study and analysis of the target building. This estimation is carried out in the Design Builder software (https://designbuilder.co.uk) and introduced into the base / main mathematical model by means of a lookup table.

\subsubsection{Mathematical model-module of the linear Fresnel collector}

The module of the linear Fresnel collector (LFC) is composed of two interconnected sub-modules: (1) the submodule of the solar collector system, represented by the mirrors, through which the collected and reflected thermal power is calculated. (2) The submodule of the absorber, through which the losses in the absorber as well as the finally absorbed and available total power in the system are estimated.

The module of the linear Fresnel collector considers the relative position of the sun to the axis of rotation of the LFC, the ambient conditions and the pre-sizing data from manufacturers, to carry out hourly, sequential, simultaneous and/or parametric analysis. In Figure 4, the flow chart of this module is presented.

1. Submodule - Solar collector system

The mathematical model of this submodule is based on [30, 31, 32]. This submodule considers the transverse and longitudinal influence of the optical performance as well as its geometric design parameters, in the calculation of the total amount of the collected and reflected thermal energy by a linear Fresnel reflector. Various configurations can also be analyzed for the relative position among the field of primary mirrors, the absorber tube and the horizontal plane.

The used equations to calculate the solar angular relationships allow to describe the apparent movement of the sun respect to the LFC. 


\section{Module of the linear Fresnel collector}

Statements and programming directives in the procedure of control of the main program, to interconnect the subprograms of the solar collector system and the absorber.

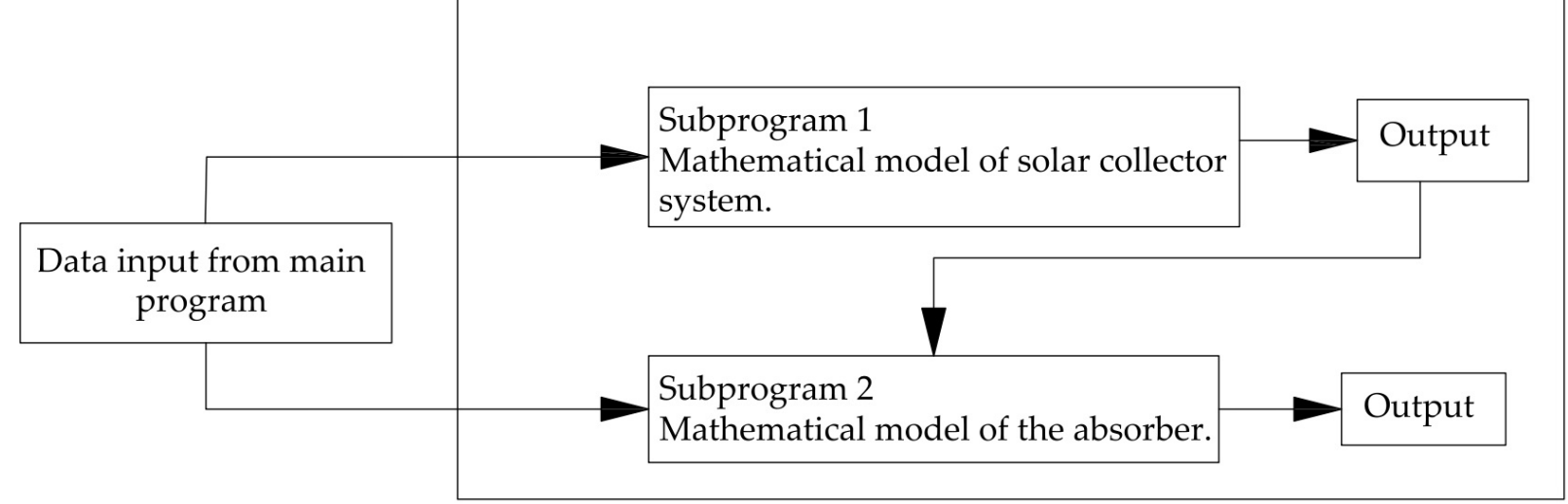

Figure 4: Structure diagram of the linear Fresnel collector module

2. Submodule - Absorber

The mathematical model of the absorber submodule is based on the equations proposed in [33] for one-dimension model. Some modifications have been made for its integration with the submodule of the solar collector system as well as with the solar cooling thermal system, object of this study.

This submodule is based on an energy balance among the heat gain reflected by the linear Fresnel collector, the heat transfer fluid and the atmosphere. It includes all equations and correlations necessary in order to estimate the terms in the energy balance from the input data. The input data includes heat gain from linear Fresnel collector, geometry and optical properties of the absorber tube, type and thermal properties of the heat transfer fluid (HTF), HTF inlet temperature, flow rate and ambient conditions.

Refer to [33] for a detailed derivation of all equations and correlations used to estimate the terms in the energy balances aforementioned, and for consulting the numerous assumptions and simplifications made in the heat collection element (HCE) performance model. These assumptions and simplifications are listed in detail in Table 2.7 of [33].

\subsubsection{Mathematical model - Storage tank mod- ule}

This module is based on [34] and consists of a simplified mathematical model of a stratified hot water storage tank with two heat exchangers and with no mass flow through the tank. The accumulated water inside the tank serves as a means of storage and energy exchange through two heat exchangers, one that provides heat energy and another that removes it and transfers it to the system, as it can be seen in the Figure 5 .

The mathematical model of the stratified hot water storage tank is formulated based on an implicit scheme and derived from carrying out an energy balance, in conjunction with various assumptions that allowed its simplification.

\subsubsection{Mathematical model -Heat exchangers module}

A well-known log mean temperature difference model is employed to evaluate the thermal behavior of the main heat exchangers. It is adjusted with suitable values of the UA parameter (the product 
Source Side $\quad$ Transfer Side

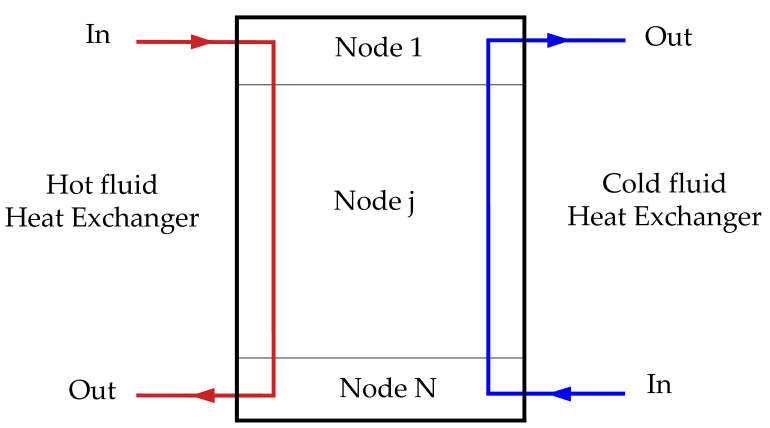

Figure 5: Schematic diagram of the storage tank considered in the mathematical model

of the overall heat transfer coefficient $U$, and the heat exchanger area $A$ ).

\subsubsection{Mathematical model - Cooling tower module}

A counter flow forced draft cooling tower has been mathematically modeled using the Merkel equation [35] in order to predict its thermal performance. Refer to [36] for a detailed explanation of the Merkel equations integration method as well as the assumptions considered.

\subsubsection{Mathematical model - Absorption chiller module}

The module of the absorption machine used in the integrated mathematical model of the solar cooling thermal system proposed in this work is based on [37] and consists in a mathematical model of a hot water fired single effect $\mathrm{LiBr}-\mathrm{H}_{2} \mathrm{O}$ absorption chiller. This model includes the effects of the heat exchange process between the cycle and its surroundings, represented by the heat exchange loops in the generator, absorber, condenser and evaporator.

A mass and energy balance have been considered for each component of the absorption cycle, as well as the relations that describe heat and mass transfer. In addition, a set of assumptions and simplifications have been contemplated in order to create a lumped component model that can be used as a representation of a realistic absorption cycle.
The heat exchange processes between the absorption cycle and its surrounding were included through the loops at generator, evaporator, condenser, and absorber, using in each component the log-mean temperature difference method and the adjusted values of the UA parameters.

Temperatures $\left(T \_1, T \_2, T \_3, T \_4, T \_5, T \_6\right.$, T_7, T_8, T_9 and $T_{-}$10), pressures $\left(P_{-} \_1, P_{-} 2\right.$, P_,3 P_4, $P_{-}, 5 P_{-} 6, P_{-} 7, P_{-} 8, P_{-}, 9$ and $\left.P_{-} 10\right)$ and qualities (X_1, X_2, X_3, X_,4 X_5, X_6, X_,7 X_8, X_9 and $\left.X \_10\right)$ at each internal state point of the thermodynamic cycle, are calculated during simulation.

Figure 6 shows the absorption cycle of the modeled chiller, where:

Tc_in_c: condenser inlet cold water temperature.

Th_out_c: condenser outlet hot water temperature. Tc_out_g: generator outlet cold water temperature. Th_in_g: generator inlet hot water temperature.

Tc_out_e: evaporator outlet cold water temperature.

Th_in_e: evaporator inlet hot water temperature.

Tc_in_a: absorber inlet cold water temperature.

Th_out_a: absorber outlet hot water temperature.

$\left(\dot{Q}_{a}\right)$ : Heat transfer rate at the absorber.

$\left(\dot{Q}_{c}\right)$ : Heat transfer rate at the condenser.

$\left(\dot{Q}_{e}\right)$ : Heat transfer rate at the evaporator.

$\left(\dot{Q}_{g}\right)$ : Heat transfer rate at the generator.

$\left(\dot{Q}_{H x}\right)$ :Heat transfer rate at the heat exchanger inside the absorption chiller

$\dot{m}[1]$ : Mass flow rate of the solution at the point 1 of the absorption cycle.

COP: Coefficient of performance.

\subsection{Case Study}

The case study consists of an hourly simulation of a solar cooling thermal installation with similar configuration to that shown in Figure 1, carried out during the month with the highest cooling demands (July).

The solar cooling thermal system has been pre-sized to satisfy the cooling demand of a typical set of electro-mechanical buildings for the maintenance of medium-capacity railway installations, located in Riyadh.

The cooling demands of the buildings have been previously calculated using the Design Builder 


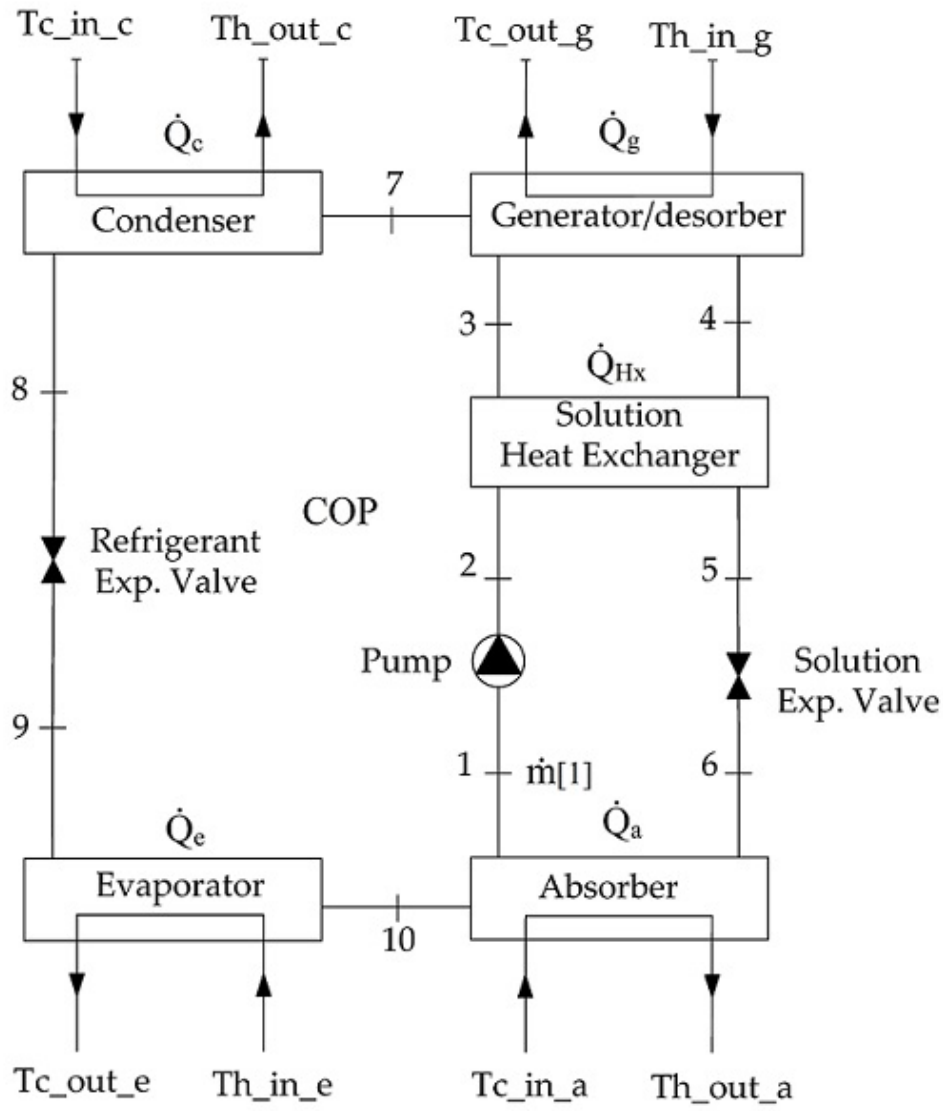

Figure 6: Hot fired single effect $\mathrm{LiBr}-\mathrm{H}_{2} \mathrm{O}$ absorption cycle with external heat transfer processes

software. The thermal loads of the building are treated by an all air system, the chilled water generated by the absorption chiller feeds an air-handling unit, which is arranged with a recirculation module and supplies the minimum required outdoor air.

The properties of the construction materials of the building (enclosures and glazing) as well as the design and use characteristics of the considered air conditioning and lighting systems are based on the requirements of the [38], according to the climatic zone of the place where the study is carried out.

The minimum outdoor air requirements are based on [39] according to the type of the space or the building to be treated. The internal thermal loads have been calculated applying a ratio of $230 \mathrm{~W} / \mathrm{m}^{2}$, derived from previously estimation of mechanical and electrical losses considered for this type of buildings. The detailed analysis done to obtain the ratio for the internal thermal loads is outside the scope of this work.

In the schematic diagram of the Figure 1 the design conditions of the proposed solar cooling system for the case study are presented. The technical and dimensional characteristics of the solar collector and the absorption chiller are included in Table 2 and Table 3 respectively.

Table 2: Technical information of linear Fresnel collector from the manufacturer datasheet

\begin{tabular}{l|c|c}
\hline \hline \multicolumn{1}{c|}{ Parameter } & Unit & Value \\
\hline Module width & $\mathrm{m}$ & 7,5 \\
Module length & $\mathrm{m}$ & 4,06 \\
Aperture area & $\mathrm{m}^{2}$ & 22 \\
Receiver height & $\mathrm{m}$ & 4 \\
Number of modules & unit & 32 \\
\hline \hline
\end{tabular}

The values of the parameters: $U A_{a}, U A_{g}, U A_{c}$, $U A_{e}$ and $\dot{m}[1]$ have been estimated through an iterative process using the mathematical model of the absorption machine in conjunction with the 

Table 3: Technical information of absorption chiller from the manufacturer datasheet

\begin{tabular}{c|c|c}
\hline \hline Parameter & Unit & Value \\
\hline$U A_{a}$ & $\mathrm{~kW} / \mathrm{K}$ & 63,732 \\
$U A_{c}$ & $\mathrm{~kW} / \mathrm{K}$ & 26,274 \\
$U A_{g}$ & $\mathrm{~kW} / \mathrm{K}$ & 73,633 \\
$U A_{e}$ & $\mathrm{~kW} / \mathrm{K}$ & 22,054 \\
$\eta_{-} H x$ & $\%$ & 65 \\
$\dot{m}[1]$ & $\mathrm{kg} / \mathrm{s}$ & 1,126 \\
\hline \hline
\end{tabular}

technical information provided by the manufacturer in the datasheet.

Table 4 list the design characteristics of the storage tank. In addition, the pressure requirements of the pumps were previously estimated through a general analysis of each sub-circuit, considering the pressure losses in the pipework, hydraulic components and in the accessories, these values are shown in Figure 1 .

Table 4: Design characteristics of the storage tank

\begin{tabular}{l|c|c}
\hline \hline \multicolumn{1}{c|}{ Parameter } & Unit & Value \\
\hline Tank inner diameter & $\mathrm{m}$ & 3,037 \\
Tank height & $\mathrm{m}$ & 4,859 \\
Thickness of the tank & $\mathrm{mm}$ & 10 \\
Thickness of the insulation & $\mathrm{W} / \mathrm{mK}$ & 50 \\
Thermal conductivity of the tank & 16,3 \\
Thermal conductivity of the insulation & $\mathrm{W} / \mathrm{mK}$ & 0,05 \\
\hline \hline The storage volume has been defined considering an \\
accumulation ratio of $50 \mathrm{~m}^{3} / \mathrm{m}^{2}$ of the collector opening area.
\end{tabular}

The operating parameters of the cooling tower (range, the ratio between the water mass flow rate $(L)$ and the air mass flow rate $(G)$, and the approach) have been defined considering the recommendations in [40] for air conditioning applications, and they are shown in Table 5. The value of the tower characteristic $(\mathrm{KaV} / \mathrm{L})$ was calculated using the mathematical model of the cooling tower. For this calculation, the values of the operating parameters and the ambient design conditions for cooling and for the hottest month of the year were considered.

Table 5: Design characteristics of the cooling tower

\begin{tabular}{c|c|c|c}
\hline \hline (KaV/L) & L/G ratio & Approach & Range \\
\hline 0,3315 & 1,2 & 11,1 & 4 \\
\hline \hline
\end{tabular}

\section{Results and Discussions}

\subsection{Verification models}

The correct implementation in the EES software and the accuracy of the mathematical models used in the development of the solar cooling thermal systems simulation tool, is demonstrated by means of a code and calculation verification. This verification is carried out through an evaluation by comparison among the numerical solutions obtained from the mathematical models in assessment regarding the known correct answers of a proposed case study or experimental results (from literature).

The convergence error $\left(\varepsilon_{\text {conv }}\right)$ is quantify using the equation (1), where $\left(V_{c e}\right)$ is the value from experimental data or literature and $\left(V_{m}\right)$ is the obtained value from the mathematical model in evaluation.

$$
\varepsilon_{c o n v}=\left|\frac{V_{c e}-V_{m}}{V_{c e}}\right| \cdot 100
$$

\subsubsection{Linear Fresnel collector-Model verifica- tion}

The numerical solutions from the simulation and the experimental data from the literature [41] are compared in order to verify the correct implementation of the proposed model for the linear Fresnel collector. The comparison is effectuated for the parameters: net absorbed solar power $\left(\dot{Q}_{A b s_{-} L F C}\right)$ and outlet water temperature of the absorber (Th_out_SCS), considering the experimental values of the direct normal irradiation (DNI) and the collector inlet temperature (Th_in_SCS).

Table 6 includes the information about the performed experimental case in the literature [41], and in Table 7 and Table 8 the verification results are presented.

According to Table 7 and Table 8, the maximum deviation between the experimental data and the numerical solution from the model is less than $10 \%$ and the mean deviation is 3,87 \% (average deviation for the analyzed hours). These results are considered as acceptable and the proposed model can be adopted as reliable to be used in the simulation tool of solar cooling thermal systems developed in the present research work. 
Table 6: Technical characteristics of the Collector

\begin{tabular}{c|c|c}
\hline \hline Variable & Unit & Value \\
\hline Length of the module & $\mathrm{m}$ & Modular steps of 4 m \\
Width of the mirror field & $\mathrm{m}$ & 7,5 \\
Aperture width & $\mathrm{m}$ & 5,5 \\
Distance between mirrors & $\mathrm{m}$ & 0,2 \\
Height of the receiver & $\mathrm{m}$ & 4 \\
Total number of mirrors & $\mathrm{ut}$ & 11 \\
Width of mirrors & $\mathrm{m}$ & 0,5 \\
Total number of modules & $\mathrm{ut}$ & 6 \\
Solar aperture area per module & $\mathrm{m}^{2}$ & 22 \\
Optical efficiency & $\%$ & 58 \\
Receiver model & - & SCHOTT PTR 70 \\
Location & - & Bergamo, Italy \\
\hline \hline
\end{tabular}

Table 7: Comparison of the results obtained from simulation and the experimental data from literature [41] - Collector outlet temperature (Th_out_SCS)

\begin{tabular}{c|c|c|c|c|c}
\hline \hline & & & \multicolumn{3}{|c}{ Th_out_SCS } \\
\cline { 4 - 6 } Time & DNI & Th_in_SCS & $\begin{array}{c}\text { Experimental } \\
\text { data }\end{array}$ & $\begin{array}{c}\text { Simulation } \\
\text { data }\end{array}$ & $\varepsilon_{\text {conv }}$ \\
$\mathrm{h}$ & $\mathrm{W} / \mathrm{m}^{2}$ & ${ }^{\circ} \mathrm{C}$ & ${ }^{\circ} \mathrm{C}$ & ${ }^{\circ} \mathrm{C}$ & $\%$ \\
\hline 8 & 548 & 95 & 98 & 96,71 & 1,32 \\
9 & 650 & 132,5 & 139 & 134,8 & 3,02 \\
10 & 675 & 147,5 & 152,5 & 149,6 & 1,9 \\
11 & 725 & 151 & 158 & 153,6 & 2,78 \\
12 & 750 & 156 & 162 & 158,6 & 2,1 \\
13 & 775 & 165 & 171 & 168 & 1,75 \\
14 & 785 & 187,5 & 195 & 190,3 & 2,41 \\
15 & 775 & 189 & 195 & 191,3 & 1,9 \\
\hline \hline
\end{tabular}

Table 8: Comparison of the results obtained from the mathematical model of the linear Fresnel collector and the experimental data from literature [41] - Net absorbed solar power $\left(\dot{Q}_{A b s_{-} L F C}\right)$

\begin{tabular}{c|c|c|c|c|c}
\hline \hline Time & & DNI $)$ & Th_in_SCS & \multicolumn{3}{|c}{$\dot{Q}_{\text {Ab__LFC }}$} \\
$\mathrm{h}$ & $\mathrm{W} / \mathrm{m}^{2}$ & $\begin{array}{c}\text { Experimental } \\
{ }^{\circ} \mathrm{C}\end{array}$ & $\begin{array}{c}\text { Simulation } \\
\text { data } \\
\mathrm{kW}\end{array}$ & $\begin{array}{c}\text { data } \\
\mathrm{kW}\end{array}$ & $\begin{array}{c}\varepsilon_{\text {conv }} \\
\%\end{array}$ \\
\hline 8 & 548 & 95 & 22,5 & 21 & 6,67 \\
9 & 650 & 132,5 & 30 & 28,743 & 4,19 \\
10 & 675 & 147,5 & 27,5 & 25,589 & 6,95 \\
11 & 725 & 151 & 30 & 32,034 & 6,78 \\
12 & 750 & 156 & 30 & 32,5 & 8,33 \\
13 & 775 & 165 & 37,5 & 36,377 & 2,99 \\
14 & 785 & 187,5 & 37,5 & 34,351 & 8,4 \\
15 & 775 & 189 & 29 & 28,89 & 0,38 \\
\hline \hline
\end{tabular}

\subsubsection{Hot water storage tank-Verification model}

The temperature profiles of the stored water and the water inside the hot and cold heat exchanger obtained from the mathematical model are compared with the experimental data from the literature [34]. This comparation is performed for values calculated at the top of the tank $(0,1 \mathrm{~m})$, in the middle $(1,1 \mathrm{~m})$ and at the bottom of the tank (1,9 m).

Comparative results and the calculated convergence error are shown in Table 9. Table 10 and Table 11. The maximum convergence error is $3,53 \%$ and the average convergence errors is $1,10 \%$ (average deviation for all analyzed variables), which are within an acceptable range. With these results, the accuracy of the mathematical model is demonstrated and its integration in the simulation tool of solar cooling thermal systems is justified.

Table 9: Temperature profile of stored water at various heights of the tank

\begin{tabular}{c|c|c|c|c}
\hline \hline \multicolumn{5}{|c}{ Stored water temperature } \\
\hline $\begin{array}{c}\text { Time } \\
\mathrm{h}\end{array}$ & $\begin{array}{c}\text { Height } \\
\mathrm{m}\end{array}$ & $\begin{array}{c}\text { Experimental } \\
\text { data } \\
\mathrm{K}\end{array}$ & $\begin{array}{c}\text { Simulation } \\
\text { data } \\
\mathrm{K}\end{array}$ & $\begin{array}{c}\varepsilon_{\text {conv }} \\
\%\end{array}$ \\
\hline 1 & & 367 & 362,24 & 1,3 \\
2 & \multirow{2}{*}{0,1} & 380 & 376,85 & 0,83 \\
3 & & 383 & 380,65 & 0,61 \\
4 & & 384 & 381,75 & 0,59 \\
\hline 1 & & 340 & 344,13 & 1,21 \\
2 & \multirow{2}{*}{1,1} & 358 & 358,94 & 0,26 \\
3 & & 364 & 363,64 & 0,1 \\
4 & & 366 & 365,11 & 0,24 \\
\hline 1 & & 324 & 331,11 & 2,19 \\
2 & \multirow{2}{*}{1,9} & 336 & 342,89 & 2,05 \\
3 & & 340 & 346,85 & 2,01 \\
4 & & 342 & 348,11 & 1,79 \\
\hline \hline
\end{tabular}

Table 10: Temperature profile of water in the hot heat exchanger at various heights of the tank

\begin{tabular}{c|c|c|c|c}
\hline \hline \multicolumn{5}{c}{ Temperature of water in the hot heat exchanger } \\
\hline $\begin{array}{c}\text { Time } \\
\mathrm{h}\end{array}$ & $\begin{array}{c}\text { Height } \\
\mathrm{m}\end{array}$ & $\begin{array}{c}\text { Experimental } \\
\text { data } \\
\mathrm{K}\end{array}$ & $\begin{array}{c}\text { Simulation } \\
\text { data } \\
\mathrm{K}\end{array}$ & $\begin{array}{c}\varepsilon_{\text {conv }} \\
\%\end{array}$ \\
\hline 1 & & 395 & 396,15 & 0,29 \\
2 & \multirow{2}{*}{, 1} & 397 & 397,65 & 0,16 \\
3 & & 398 & 398,05 & 0,01 \\
4 & & 398 & 398,15 & 0,04 \\
\hline 1 & & 370 & 376,95 & 1,88 \\
2 & \multirow{2}{*}{1,1} & 381 & 384,15 & 0,83 \\
3 & & 384 & 386,25 & 0,59 \\
4 & & 386 & 386,95 & 0,25 \\
\hline 1 & & 350 & 362,36 & 3,53 \\
2 & \multirow{2}{*}{1,9} & 364 & 371,61 & 2,09 \\
3 & & 368 & 374,55 & 1,78 \\
4 & & 370 & 375,45 & 1,47 \\
\hline \hline
\end{tabular}


Table 11: Temperature profile of water in the cold heat exchanger at various heights of the tank

\begin{tabular}{c|c|c|c|c}
\hline \hline \multicolumn{5}{c}{ Temperature of water in the cold heat exchanger } \\
\hline $\begin{array}{c}\text { Time } \\
\mathrm{h}\end{array}$ & $\begin{array}{c}\text { Height } \\
\mathrm{m}\end{array}$ & $\begin{array}{c}\text { Experimental } \\
\text { data } \\
\mathrm{K}\end{array}$ & $\begin{array}{c}\text { Simulation } \\
\text { data } \\
\mathrm{K}\end{array}$ & $\begin{array}{c}\varepsilon_{\text {conv }} \\
\%\end{array}$ \\
\hline 1 & & 336 & 341,06 & 1,51 \\
2 & \multirow{2}{*}{0,1} & 350 & 352,9 & 0,83 \\
3 & & 356 & 356,41 & 0,12 \\
4 & & 358 & 357,46 & 0,15 \\
\hline 1 & & 311 & 321,78 & 3,47 \\
2 & \multirow{2}{*}{1} & 322 & 329,52 & 2,34 \\
3 & & 328 & 331,74 & 1,14 \\
4 & & 330 & 332,84 & 0,86 \\
\hline 1 & & 302 & 304,76 & 0,91 \\
2 & \multirow{2}{*}{1,9} & 304 & 306,58 & 0,85 \\
3 & & 305 & 307,17 & 0,71 \\
4 & & 306 & 307,36 & 0,44 \\
\hline \hline
\end{tabular}

\subsubsection{Absorption Machine - Verification model}

In order to verify the accuracy of the absorption machine model, the obtained numerical solutions from the simulation and the results from literature [42] are compared. This comparation is performed for the operating parameters and each internal state of the absorption chiller.

Comparative results and the calculated convergence error are shown in Table 12 and Table 13 . Due to the large number of variables and internal thermodynamic states of the absorption machine as well as the interactive operating parameters analyzed, the model verification is carried out considering an average convergence error, which results in $0,4788 \%$. The deviation is small enough to prove the accuracy of the model and its integration as a module in the simulation tool of solar cooling thermal systems is justified.

\subsubsection{Cooling tower-Verification model}

The accuracy and the correct implementation of the cooling tower model is verified by comparing the numerical solutions from simulation with the data from the literature [43]. This comparation is performed for the following parameters: enthalpy of the film $\left(h_{a}^{\prime}\right)$, enthalpy of moist air $\left(h_{a}\right)$, enthalpy of air stream leaving the cooling tower $\left(h_{a \_s}\right)$, and the cooling tower characteristic $(\mathrm{KaV} / \mathrm{L})$. Comparative results and the calculated convergence errors are shown in Table 14 .

The calculated convergence error $\left(\varepsilon_{\text {conv }}\right)$ for each
Table 12: Internal states parameters - Comparison of the results obtained from the mathematical model of the absorption chiller and the correct answer values from literature [42]

\begin{tabular}{|c|c|c|c|c|}
\hline \multicolumn{2}{|c|}{$\begin{array}{c}\text { Internal } \\
\text { Parameters }\end{array}$} & $\begin{array}{l}\text { Values from } \\
\text { literature [42] }\end{array}$ & $\begin{array}{c}\text { Simulation } \\
\text { data }\end{array}$ & $\begin{array}{c}\varepsilon_{\text {conv }} \\
\%\end{array}$ \\
\hline T_1 & ${ }^{\circ} \mathrm{C}$ & 40,7 & 40,02 & 1,671 \\
\hline T_6 & ${ }^{\circ} \mathrm{C}$ & 49,9 & 51,14 & 2,48 \\
\hline X_1 & $\%$ & 59,6 & 60,2 & 1,01 \\
\hline X_4 & $\%$ & 64,6 & 65,28 & 1,05 \\
\hline T_4 & ${ }^{\circ} \mathrm{C}$ & 103,5 & 104,1 & 0,58 \\
\hline T_7 & ${ }^{\circ} \mathrm{C}$ & 92,4 & 91,67 & 0,79 \\
\hline T_3 & ${ }^{\circ} \mathrm{C}$ & 76,1 & 75,89 & 0,28 \\
\hline T_3 & ${ }^{\circ} \mathrm{C}$ & 76,1 & 75,89 & 0,28 \\
\hline T_5 & ${ }^{\circ} \mathrm{C}$ & 62,4 & 62,21 & 0,3 \\
\hline m_6 & $\mathrm{kg} / \mathrm{s}$ & 11,06 & 11,07 & 0,09 \\
\hline T_9 & ${ }^{\circ} \mathrm{C}$ & 1,8 & 1,787 & 0,72 \\
\hline P_9 & $\mathrm{kPa}$ & 0,697 & 0,6953 & 0,24 \\
\hline T_8 & ${ }^{\circ} \mathrm{C}$ & 46,2 & 46,17 & 0,06 \\
\hline P_ 8 & $\mathrm{kPa}$ & 10,2 & 10,19 & 0,1 \\
\hline
\end{tabular}

Table 13: Operating parameters - Comparison of the results obtained from the model of the absorption chiller and the and the correct answer values from literature [42]

\begin{tabular}{c|c|c|c|c}
\hline \hline \multicolumn{2}{c|}{$\begin{array}{c}\text { Performance } \\
\text { Parameters }\end{array}$} & $\begin{array}{c}\text { Values from } \\
\text { literature [42] }\end{array}$ & $\begin{array}{c}\text { Simulation } \\
\text { data }\end{array}$ & $\begin{array}{c}\varepsilon_{\text {conv }} \\
\%\end{array}$ \\
\hline$\dot{Q}_{c}$ & $\mathrm{~kW}$ & 2322 & 2313,5 & 0,37 \\
$\dot{Q}_{a}$ & $\mathrm{~kW}$ & 2984 & 3007,667 & 0,79 \\
$\dot{Q}_{g}$ & $\mathrm{~kW}$ & 3158 & 3163,852 & 0,19 \\
$\dot{Q}_{H x}$ & $\mathrm{~kW}$ & 825 & 827,7 & 0,33 \\
$\mathrm{COP}$ & - & 0,68 & 0,6818 & 0,26 \\
\hline \hline
\end{tabular}

variable is less than $1 \%$, indicating an acceptable level of precision and convergence. Therefore, the integration of this model as a module in the simulation tool of solar cooling thermal systems is justified.

Table 14: Comparison of the results obtained from the model of the cooling tower and the correct answer values from literature [43]

\begin{tabular}{c|c|c|c|c}
\hline \hline \multicolumn{2}{c|}{$\begin{array}{c}\text { Design and } \\
\text { operating } \\
\text { parameters }\end{array}$} & $\begin{array}{c}\text { Values from } \\
\text { literature [43] }\end{array}$ & $\begin{array}{c}\text { Simulation } \\
\text { data }\end{array}$ & $\begin{array}{c}\varepsilon_{\text {conv }} \\
\%\end{array}$ \\
\hline$h_{a}$ & $\mathrm{~kJ} / \mathrm{kg}$ & 72,4 & 71,81 & 0,81 \\
$h_{a_{-} s}$ & $\mathrm{~kJ} / \mathrm{kg}$ & 112,3 & 111,9 & 0,36 \\
$h_{a}^{\prime}$ & $\mathrm{kJ} / \mathrm{kg}$ & 150,7 & 150,2 & 0,33 \\
$\mathrm{Approach}$ & $\mathrm{K}$ & 6 & 5,999 & 0,02 \\
$\sum \mathrm{NTU}$ & - & 1,0765 & 1,071 & 0,51 \\
orKaV/L & & & & \\
\hline \hline
\end{tabular}




\subsection{Case study results}

The obtained results from the hourly simulation of the case study, were grouped, exported, and used according to the objectives pursued by the authors. The tool offers the possibility of analyzing the behavior of the studied installation in a globally way or focused on any of its components, permitting to know the simultaneous influence of one or more variables on others, as shown in the figures below. In these figures, some graphs are presented with information considered relevant to demonstrate the capability of the tool, but not limited to it.

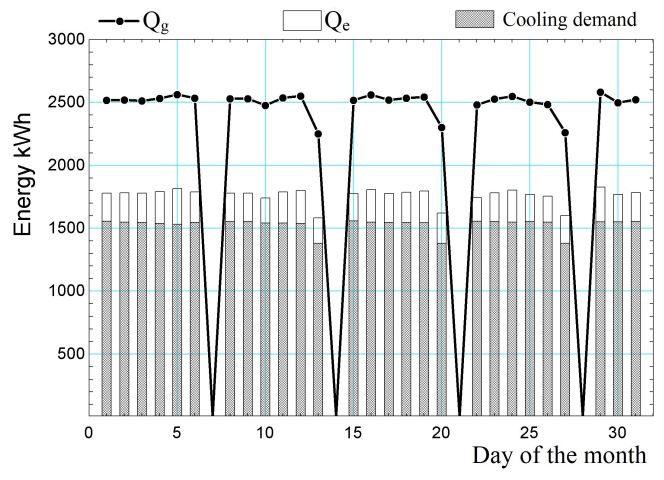

Figure 7: Cooling energy generated vs cooling demand during July

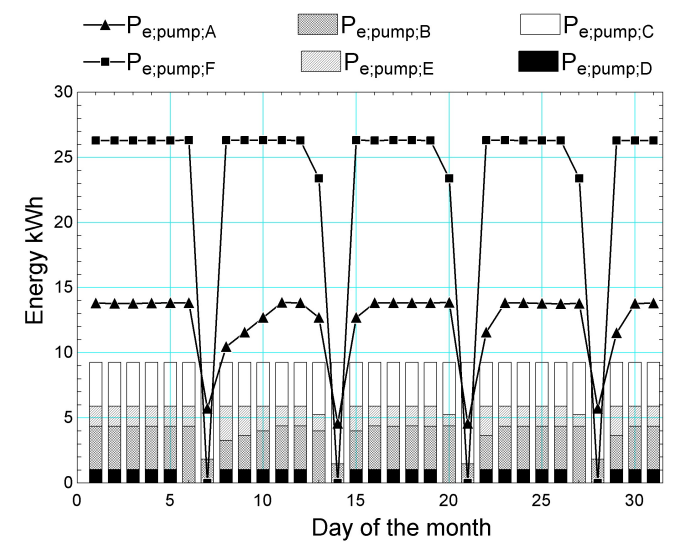

Figure 8: Electric consumption of the pumps in each subcircuit during July

It is important to mention that the main objective of the simulation carried out is to show the operation of the developed tool as well as its capabilities. It is not within the scope of this work to optimize the operation and design of the studied installation.

Figure 7 shows the cooling energy $(Q e)$ generated by the absorption machine for each day of the month of July from the heat energy supplied in the generator $(Q g)$. Furthermore, it is observed that the cooling demand of the building is satisfied for each day of the month. In Figure 8 the electrical consumption of the pumps in each of the subcircuits is presented $\left(E_{\text {pump_A }}, E_{\text {pump_B }}, E_{\text {pump_C }}, E_{\text {pump_D }}\right.$, $E_{\text {pump_E }}$ and $\left.E_{\text {pump_F }}\right)$.

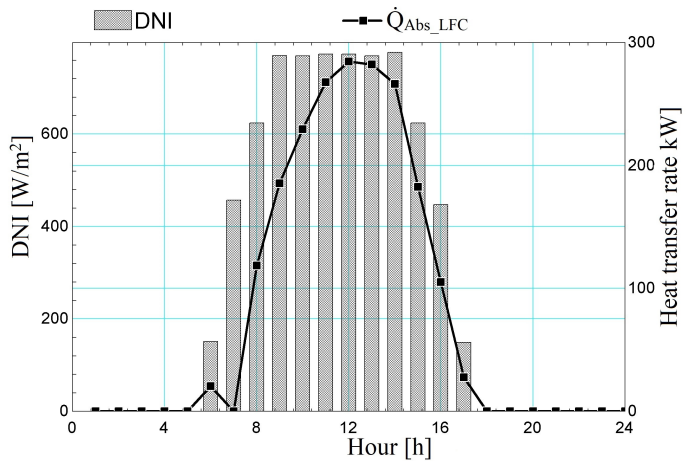

Figure 9: Direct normal irradiation in Riyadh vs the rate of the net energy absorbed in the LFC

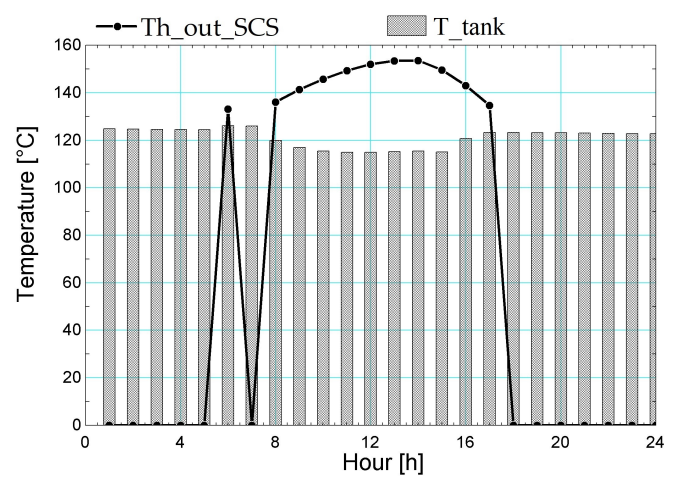

Figure 10: LFC hot water outlet temperature and the average temperature of the stored water (T_tank) on July 15

Figure 9 shows the rate of the net energy absorbed in the linear Fresnel collector system on July 15 versus the available direct normal irradiance. For the same day, Figure 10 illustrates the hourly distribution of the average temperature of the stored water ( $T_{-}$tank) and the hot water leaving the collector. 
In Figure 11 the stratification in the hot water storage tank throughout the day of July 15 is shown. Line graph in Figure 12 illustrates the behavior of the hot water storage tank on July 15, showing the hourly distribution of the stored water average temperature, the tank inlet hot water temperature (Th_in_ST) coming from the heat exchanger of the solar system and the tank outlet hot water temperature (Tc_out_ST) that feeds the absorption machine.

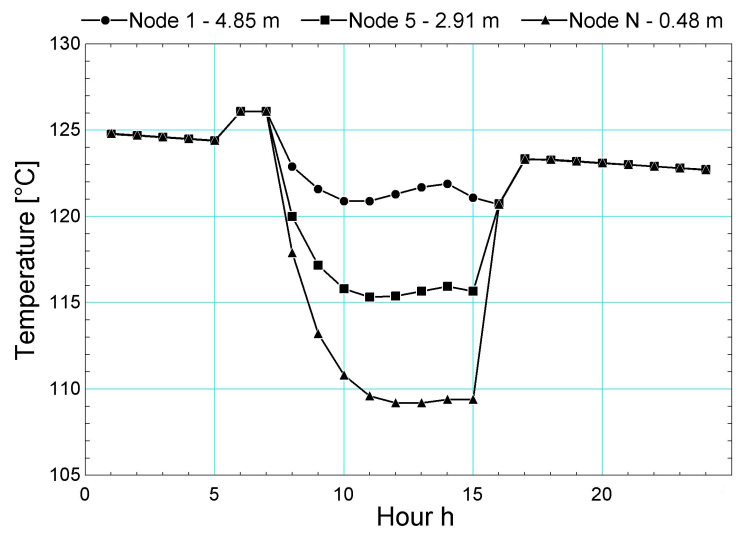

Figure 11: Hourly stratification of the hot water storage tank in July 15

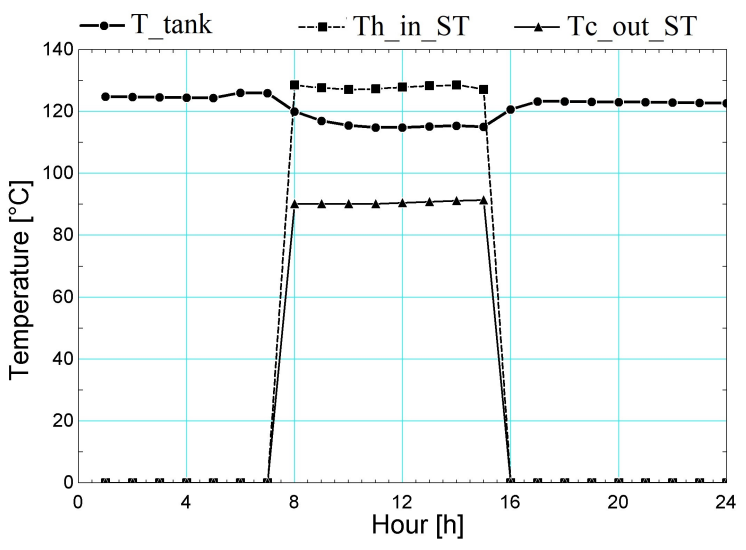

Figure 12: Temperatures in the hot water storage tank in July 15

In addition, from Figure 12 it can be seen that the heat losses towards the surroundings during the night are almost negligible (the average temperature of the tank falls from $124,8^{\circ} \mathrm{C}$ to $\left.124,4^{\circ} \mathrm{C}\right)$. The average temperature inside the tank has remained oscillating between $124^{\circ} \mathrm{C}$ and $114,9^{\circ} \mathrm{C}$ during the day, reaching a value of $126,1^{\circ} \mathrm{C}$ at 6:00 a.m.

Figure 13 shows the heat transfer rate in the various internal components of the absorption machine for each hour of the design day according to the hot water temperature entering the generator (Th_in_g). In Figure 14 it is observed that for each hour of the design day, the studied solar cooling thermal system not only satisfies the cooling demand of the building but there is also a surplus.

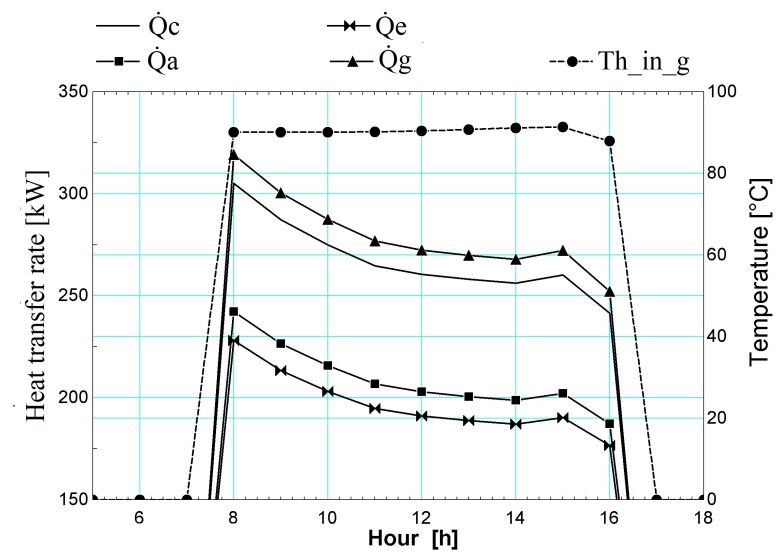

Figure 13: Hourly heat transfer rate in the components of the absorption chiller on July 15 vs the generator inlet hot water temperature

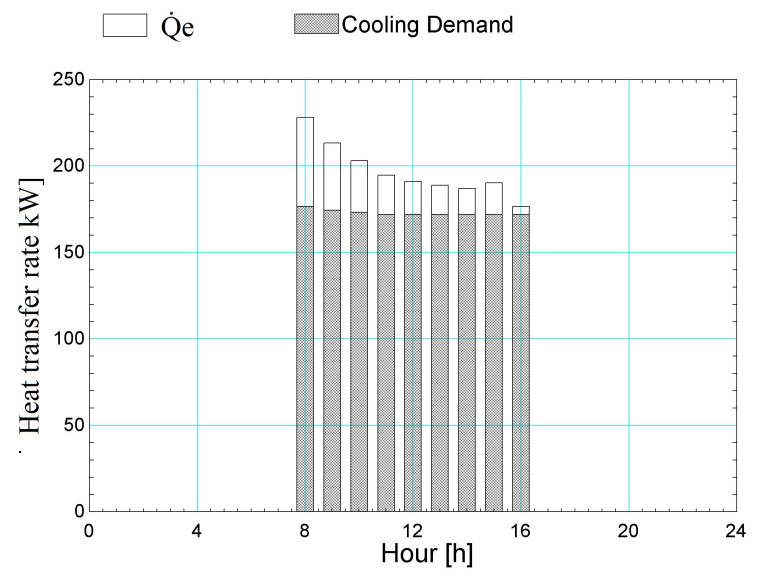

Figure 14: Hourly cooling demand of the system and the cooling power generated by the absorption chiller on July 15

In the Figure 15 it is presented the simultaneous influence of the water temperature entering in the desorber and the water temperature leaving the 
cooling tower (Tc_out_Ct) on the COP value of the absorption machine.

It is observed, how an increase of temperature in the cold water leaving the cooling tower causes a decrease in the value of the COP at the same value of the hot water temperature entering the generator. The aforementioned behavior is observed at 8:00 $\mathrm{h}$ and 11:00 $\mathrm{h}$ (the COP value decreases from 0,714 to 0,703 when the temperature of water leaving the cooling tower increases from $26,63{ }^{\circ} \mathrm{C}$ to $29,8^{\circ} \mathrm{C}$ while the temperature of water entering the desorber is $90,1^{\circ} \mathrm{C}$ ).

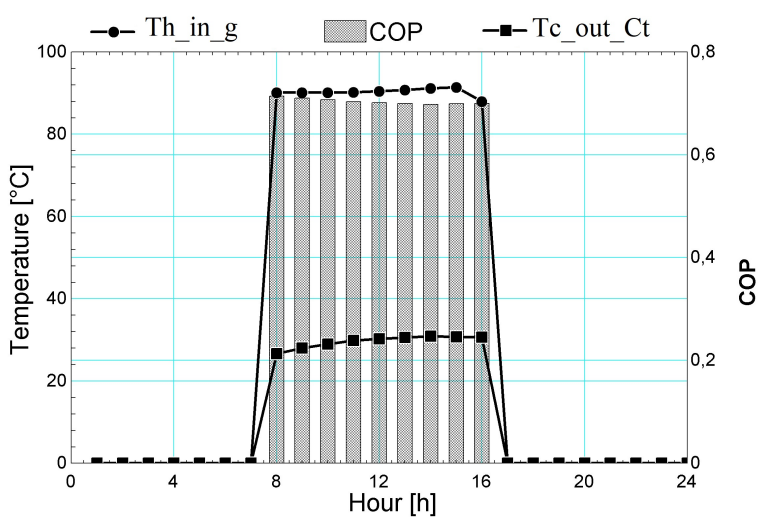

Figure 15: COP of the absorption chiller vs outlet cooled water temperature of the cooling tower and the inlet hot water temperature of the generator

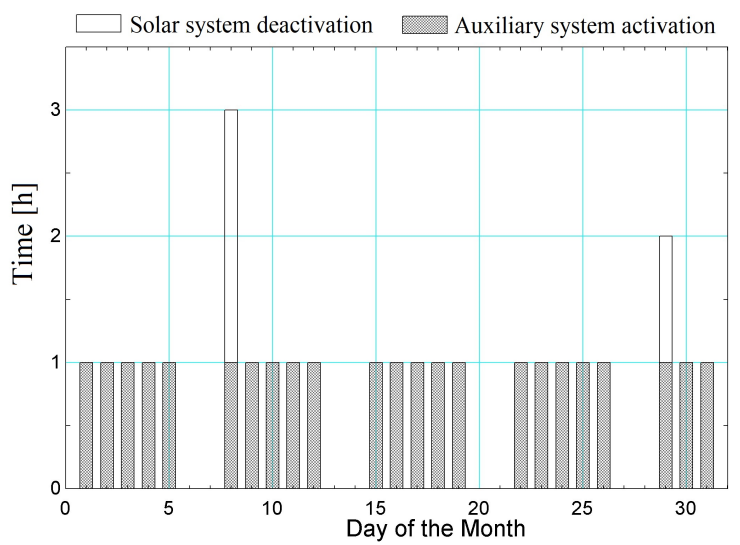

Figure 16: Hours of disconnection of the solar system and activation of the auxiliary system

As can be seen in the Figure 16, during the month of July the solar system was deactivated during 5 h. This deactivation was carried out by the control system due to an increase in the set temperature inside the tank.

The auxiliary conventional system was activated during $23 \mathrm{~h}$, all times to supply thermal energy to the absorption machine while the solar collector system supplied energy to the tank to adjust its temperature, mainly in the early hours of the morning.

These results indicate, the scarce energy contribution by the auxiliary system (8,32 \% of the energy required) as well as the correct dimensioning of the installation, reflected in the reduced number of hours of deactivation of the solar system.

\section{Conclusions}

The mathematical model of the developed simulation tool in this work, was created with the objective that it was a useful and realistic representation of a solar cooling thermal system driven by linear Fresnel collector.

Through this tool, it is possible to:

a) correctly analyze this type of installations in a globally way or focused on the individual performance of its components,

b) optimize the dimensioning of the system components and to develop operational and controlling strategies,

c) study experimental data and

d) perform design optimization of the individual parts and components of the system.

The inclusion and coupling of a module for the simulation of linear Fresnel collector in a solar cooling thermal system constitutes one of the main novelties of this work.

The developed simulation tool is characterized by been user-oriented and with special utilities that enable graphing the results. Furthermore, the user can define the features of the system components from real pre-sizing data.

The applicability, functionality and virtues of the developed tool was demonstrated by carrying out a case study. This was performed for the month of 
July, with a solar opening area of $704 \mathrm{~m}^{2}$ and a hot water storage capacity of $50 \mathrm{~L} / \mathrm{m}^{2}$ of solar opening area.

The heat transfers rates, temperatures profiles and electrical consumption of the different components of the system were hourly calculated, graphed and analyzed for the study month and design day (July 15).

During the study month, the system generated a total cooling energy of $47,585 \mathrm{MWh}$, meeting the cooling demand of the building. The COP daily value of the absorption machine remained above 0,69 .

The solar collector system was deactivated $5 \mathrm{~h}$ during the month due to an increase in the set temperature inside the tank. For that same period, the auxiliary conventional system operated just $23 \mathrm{~h}, 100 \%$ of the times to supply energy to the absorption machine while the solar collector system supplied energy to the tank to adjust its temperature.

\section{References}

[1] IEA (International Energy Agency), “The future of cooling-opportunities for energy efficient air conditionning." OECD/IEA, Paris, techreport, 2018.

[2] W. Sparber, A. Napolitano, and P. Melograno, "Overwiew on world wide installed solar cooling systems," in 2nd International Conference Solar Air Conditioning, Tarragona, Spain, 2007.

[3] W. Werner and M. Spörk-Dür, Solar Heat Worldwide. Global Market Development and Trends in 2018. Detailed Market Figures 2017. Gleisdorf, Austria: AEE - Institute for Sustainable Technologies, 2019.

[4] E. Bellos, C. Tzivanidis, N. Zervas, G. Mitsopoulos, and K. A. Antonopoulos, "Energetic and Financial Comparison between a 1-Stage Absorption Chiller Driven by FPC and a 2-Stage Absorption Chiller Driven by PTC," in Proceedings of the World Congress on Momentum, Heat and Mass Transfer, Prague, Czech Republic, 2016. https://doi.org/10.11159/ichtd16.102

[5] J. A. Aguilar-Jiménez, N. Velázquez, R. López-Zavala, L. A. González-Uribe, R. Beltrán, and L. HernándezCallejo, "Simulation of a solar-assisted air-conditioning system applied to a remote school," Appl. Sci., vol. 9, no. 16, p. 3398, 2019. https://doi.org/10.3390/ app9163398

[6] A. Al-Falahi, F. Alobaid, and B. Epple, "Design and Thermo-Economic Comparisons of an Absorption Air Conditioning System Based on Parabolic Trough and Evacuated Tube Solar Collectors," Energies, vol. 13 , no. 12 , p. 3198,2020 . https://doi.org/10.3390/ en 13123198

[7] S. Mehmood, S. A. Maximov, H. Chalmers, and D. Friedrich, "Energetic, Economic and Environmental (3E) Assessment and Design of Solar-Powered HVAC Systems in Pakistan," Energies, vol. 13, no. 17, p. 4333, 2020. https://doi.org/10.3390/en13174333

[8] M.-J. Suárez López, J.-I. Prieto, E. Blanco, and D. García, "Tests of an Absorption Cooling Machine at the Gijón Solar Cooling Laboratory," Energies, vol. 13, no. 15, p. 3962, 2020. https://doi.org/10.3390/ en13153962

[9] J. Cerezo, R. J. Romero, J. Ibarra, A. Rodríguez, G. Montero, and A. Acuña, "Dynamic simulation of an absorption cooling system with different working mixtures," Energies, vol. 11, no. 2, p. 259, 2018. https://doi.org/10.3390/en11020259

[10] B. Prasartkaew, "Mathematical modeling of an absorption chiller system energized by a hybrid thermal system: Model validation," Energy Procedia, vol. 34, pp. 159-172, 2013. https://doi.org/10.1016/j.egypro. 2013.06.744

[11] Y. Agrouaz, T. Bouhal, A. Allouhi, T. Kousksou, A. Jamil, and Y. Zeraouli, "Energy and parametric analysis of solar absorption cooling systems in various Moroccan climates," Case Studies in Thermal Engineering, vol. 9, pp. 28-39, 2017. https://doi.org/ 10.1016/j.csite.2016.11.002

[12] I. B. Butt, J. Tan, A. Waqas, M. Ali, A. Javed, and A. Y. Ali, "Effect of Modified Flow Schemes of Heat Transfer Fluid on the Performance of a Solar Absorption-Cooling System for an Educational Building in Pakistan," Applied Sciences, vol. 10, no. 9, p. 3327, 2020. https://doi.org/10.3390/app10093327

[13] J. Albers, "Improved Solar Operation Control for a Solar Cooling System of an IT Center," Applied Sciences, vol. 10, no. 9, p. 3354, 2020. https://doi.org/ 10.3390/app10103354

[14] A. Al-Falahi, F. Alobaid, and B. Epple, "ThermoEconomic Evaluation of Aqua-Ammonia Solar Absorption Air Conditioning System Integrated with Various Collector Types," Entropy, vol. 22, p. 1165, 2020. https://doi.org/10.3390/e22101165

[15] L. Huang, R. Zheng, and U. Piontek, "Installation and Operation of a Solar Cooling and Heating System Incorporated with Air-Source Heat Pumps," Energies, vol. 12, no. 6, p. 996, 2019. https://doi.org/10.3390/ en 12060996

[16] A. C. Abrudan, O. G. Pop, A. Serban, and M. C. Balan, "New Perspective on Performances and Limits of Solar Fresh Air Cooling in Different Climatic Conditions," Energies, vol. 12, no. 11, p. 2113, 2019. https://doi.org/10.3390/en12112113

[17] C. Stanciu, D. Stanciu, and A.-T. Gheorghian, "Thermal Analysis of a Solar Powered Absorption Cooling System with Fully Mixed Thermal Storage at Startup," 
Energies, vol. 10, no. 1, p. 72, 2017. https://doi.org/10. 3390/en10010072

[18] Y. Galindo Luna, W. Gómez Franco, U. Dehesa Carrasco, R. Romero Domínguez, and J. Jiménez García, "Integration of the Experimental Results of a Parabolic Trough Collector (PTC) Solar Plant to an Absorption Air-Conditioning System," Applied Sciences, vol. 8, no. 11, p. 2163, 2018. https://doi.org/10.3390/ app8112163

[19] M. H. Ahmed, "Effect of solar collector area and storage tank capacity on the performance of the absorption chiller," International Journal of Renewable Energy Research-IJRER, vol. 10, no. 1, pp. 175-182, 2020.

[20] J. Wang, R. Yan, Z. Wang, X. Zhang, and G. Shi, "Thermal Performance Analysis of an Absorption Cooling System Based on Parabolic Trough Solar Collectors," Energies, vol. 11, p. 2679, 2018. https: //doi.org/10.3390/en11102679

[21] E. Camacho, A. Gallego, A. Sanchez, and M. Berenguel, "Incremental State-Space Model Predictive Control of a Fresnel Solar Collector Field," Energies, vol. 12, no. 1, pp. 1-23, 2018. https://doi.org/ $10.3390 /$ en 12010003

[22] H. Wang, "Performance Evaluation of a Small Scale Modular Solar Trigeneration System," International Journal of Photoenergy, vol. 2014, p. 964021, 2014. https://doi.org/10.1155/2014/964021

[23] R. Buck and S. Friedmann, "Solar-Assisted Small Solar Tower Trigeneration Systems," Journal of Solar Energy Engineering, vol. 129, no. 4, pp. 349-354, 2007. https://doi.org/10.1115/1.2769688

[24] Y. Dabwan and P. Gang, "Thermo-economic analysis of integrated linear Fresnel reflector gas turbine trigeneration power plants," in IOP Conference Series: Materials Science and Engineering. 9th Edition of the International SOLARIS Conference 30-31 August 2018, vol. 556, Chengdu, China, 2019. https://doi.org/ 10.1088/1757-899X/556/1/012023

[25] F. Rovense, M. Romero, J. Gonzalez-Aguilar, and M. Reyes Belmonte, "Combined heat/cooling and power generation using hybrid micro gas turbine in a CST plant for a residential off-grid application," in AIP Conference Proceedings, vol. 2303, no. 1. AIP Publishing, 2020. https://doi.org/10.1063/5.0029285

[26] A. Khaliq, M. A. Alharthi, S. Alqaed, E. M. A. Mokheimer, and R. Kumar, "Analysis and Assessment of Tower Solar Collector Driven Trigeneration System," Journal of Solar Energy Engineering, vol. 142, no. 5, p. 051003, 2020.

[27] E. Bellos and C. Tzivanidis, "Parametric Investigation of a Trigeneration System with an Organic Rankine Cycle and Absorption Heat Pump Driven by Parabolic Trough Collectors for the Building Sector," Energies, vol. 13, no. 7, p. 1800, 2020. https://doi.org/10.3390/ en13071800

[28] J. P. Osborne, P. Kohlenbach, U. Jakob, J. Dreyer, and
J. Kim, "The Design and Installation of a Combined Concentrating Power Station, Solar Cooling System and Domestic Hot Water System," Energy Procedia, vol. 70, pp. 486-494, 2015. https://doi.org/10.1016/j. egypro.2015.02.152

[29] L. Cioccolanti, M. Villarini, R. Tascioni, and E. Bocci, "Performance assessment of a solar trigeneration system for residential applications by means of a modelling study," Energy Procedia, vol. 126, pp. 445-452, 2017. https://doi.org/10.1016/j.egypro.2017. 08.211

[30] A. Barbón, N. Barbón, L. Bayón, and J. A. Otero, "Theoretical elements for the design of a small scale Linear Fresnel Reflector: Frontal and lateral views," Sol. Energy, vol. 132, pp. 188-202, 2016. https://doi. org/10.1016/j.solener.2016.02.054

[31] A. Barbón, N. Barbón, L. Bayón, and J. A. Otero, "Optimization of the length and position of the absorber tube in small-scale Linear Fresnel Concentrators," Renewable Energy, vol. 99, pp. 986-995, 2016. https: //doi.org/10.1016/j.renene.2016.07.070

[32] A. Barbón, N. Barbón, L. Bayón, and J. A. SánchezRodríguez, "Parametric study of the small scale linear Fresnel reflector," Renewable Energy, vol. 116, pp. 6474, 2018. https://doi.org/10.1016/j.renene.2017.09.066

[33] R. Forristall, Heat Transfer Analysis and Modeling of a Parabolic Trough Solar Receiver Implemented in Engineering Equation Solver. Colorado, USA: National Renewable Energy Laboratory, 2003.

[34] A. Rahman, N. Fumo, and A. D. Smith, "Simplified modeling of thermal storage tank for distributed energy heat recovery applications," in Proceedings of the ASME 2015 Power and Energy Conversion Conference, American Society of Mechanical Engineers, San Diego, USA, 2015. https://doi.org/10.1115/ES2015-49170

[35] J. C. Kloppers and D. G. Kröger, "Cooling tower performance: A critical evaluation of Merkel assumptions," $R \& D$ Journal, vol. 20, no. 1, pp. 2429, 2004. http://hdl.handle.net/10019.1/78962

[36] D. Baker and H. Shryock, "A Comprehensive Approach to the Analysis of Cooling Tower Performance," Journal of Heat Transfer, vol. 83, no. 3, pp. 339-349, 1961. https://doi.org/10.1115/1.3682276

[37] K. Herold, R. Radermacher, and S. Klein, Absorption Chillers and Heat Pump. Boca Ratón, USA: CRC Press, 1996.

[38] ASHRAE, Standard 90.1-2016. Energy Standard for Buildings Except Low-Rise Residential Buildings. Atlanta, GA, USA: American Society of Heating, Refrigerating, and Air-Conditioning Engineers, 2016.

[39] ASHRAE, ANSI/ASHRAE Standard 62.1-2019, Ventilation for Acceptable Indoor Air Quality. Atlanta, GA, USA: American Society of Heating, Refrigerating, and Air-Conditioning Engineers, 2019.

[40] B. Chowdhury, M. Islam, F. Begum, and A. Parvez, "Design and Performance Analysis of a Cooling 
Tower in Sulfuric Acid Plant," Journal of Chemical Engineering, 2010. https://doi.org/10.3329/jce.v23i0. 5568

[41] A. Häberle, F. Luginsland, C. Zahler, M. Berger, M. Rommel, and H. M. Henning, "A linear concentrating Fresnel collector driving a $\mathrm{NH}_{3}-\mathrm{H}_{2} \mathrm{O}$ absorption chiller," in Proc. Second Int. Conf. Sol. AirConditioning, Tarragona, Spain, 2007, pp. 662-667.

[42] ASHRAE, "Chapter 2 - Thermodynamics and Refrigeration Cycles," in 2017 ASHRAE Handbook Fundamentals. Atlanta, GA, USA: American Society of Heating, Refrigerating, and Air-Conditioning Engineers, 2017.

[43] ASHRAE, "Chapter 40 - Cooling Towers," in 2020 ASHRAE Handbook-HVAC Systems and Equipment. Atlanta, GA, USA: American Society of Heating, Refrigerating, and Air-Conditioning Engineers, 2020. 